\section{WILD POTATOES}

The Potatoes of Argentina, Brazil, Paraguay and Uruguay A Biosystematic Study. By J. G. Hawkes and J. P. Hjerting. (Annals of Botany Memoirs, No. 3.) Pp. xxiii $+525+150$ plates. (Clarendon Press: Oxford; Oxford University Press: London, March 1969.) $210 s$.

THis book is mainly concerned with the wild potato species of eastern South America, only some seventeen pages being devoted to the cultivated potatoes of the area. Professor Hawkes has collected in north-west and south-east Argentina, in Bolivia, Uruguay and south Brazil and Dr Hjerting in south, west, north-west, north and north-east provinces of Argentina and also in Bolivia. The authors have also had talks with Argentine, Brazilian and European collectors who have visited regions not known to them and received material from these collectors. They have examined specimens in several herbaria and have studied material grown from their collections in England and Denmark for several years. Clearly this memoir, whatever its faults, will be for many years the standard work on the potatoes of this part of South America.

()f the nineteen wild species described, seventeen are diploids, one (Solanum calvescens) is so far known only as triploid elones, and one (S. acule) is a tetraploid. The diploid species belong to the five series, Etuberosa, Commersoniana, Cuneolata, Megistacroloba and Tuberosa. $S$. acaule (the tetraploid species) is the only species in the series Acaulia. In considering each series the authors have taken a conservative and rather broad view and have tried not to split them up more than was necessary. It was therefore possible during the course of the work in assessing critically 96 specific and 64 infraspecific taxa described previously to reduce them with a reasonable degree of certainty to 22 species and 12 subspecies.

Not all taxonomists would agree with the authors' concept of the "biological species", one in which the species boundaries on paper relate directly to reproductive barriers of some sort in nature. As all the diploid species can be crossed to give fertile hybrids with regular meiotic divisions, applying this concept to them is difficult. The species boundaries are presurnably mostly geographical or ecological. In some cases the biological boundary has been studied by observing breakdown in $\mathrm{F}_{2}$ progenies. This has not been earried out for every species because of the effort required. Thus, for example, it is stated that "S. kurtzianum seems to us to be a good species, with welldefined distribution area and ecological requirements. At the northern end of its range it perhaps hybridizes with S. spegazzinii and exchanges genes with it. Nevertheless, the two species seem too distinct to be considered as two subspecies of a single species". One is therefore left wondering whether the concept of a "biological species" is necessary and whether one should be content on the contrary with the old definition of a good species as being one which a competent taxonomist considers to be a good species.

The main part of the book is divided into two parts, general and detailed taxonomy, the lattor being more than twice the size of the former. One chapter in the general section discusses the value to the potato breeder of the wild species. S. acaule has been used as a source of frost resistance and several of the diploid species may be useful in breeding for resistance to potato cyst-nematode (Heterodera rostochiensis). For most of the other pests and diseases ennsidered, however, better and more readily usable sources of resistance are available in cultivated or other species of wild potatoes. It should also be noted that the high protein contents of the small tubers of the wild species are found because they are small tubers. As in other plants, the maximum yield of protein per acre in potatoes is obtained from a high total yield of material of low protein content.

\section{LIBRARY SERVICES TO INDUSTRY}

\section{Industrial Libraries Throughout the World}

By K. G. B. Bakewell. (International Series of Mono. graphs in Library and Information Science, Vol. 11.) Pp. viii +184 . (Pergamon Press: Oxford, London and New York, March 1969.) $56 s ; \$ 7.50$.

DURING the 1960 s interest has developed in comparative studies in librarianship and information work, but to date very little has been published in the English language and one applauds this series of International Series of Monographs in Library and Information Science as an attempt to fill this gap. Mr Bakewell has produced Industrial Libraries Throughout the World with three groups of readers in mind; first, government officials and industrial managers who may assume responsibility for industrial libraries; second, industrial librarians wishing to communicate with colleagues in other countries; and third, the student (presumably of comparative librarianship). The link between libraries and productivity, and the international scene of library and information services, are discussed. Then there is a description of industrial libraries throughout the world country by country, and the book finishes with a chapter entitled "Manag. ing the Industrial Library" and a list of 284 references. I feol that the aims and attempted coverage of this book are too wide, and that it is unlikely to satisfy the needs of the three groups of readers that the author had in mind. For government officials and indus. trial managers the chapters on libraries and productivity: the international scene, libraries in Great Britain and Ireland and those of other European countries, together with that dealing with the management of the library, will be of interest. They are hardly likely to be interested in libraries in Korea. The industrial librarian wishing to contact colleagues will find the chapters arranged b! country disappointing, because the coverage varien considerably; for example, Switzerland has four inajor pharmaceutical companies with important collections. in their subject fields located at Basel-one of these rates five lines, the others are not mentioned. For the student, a comparative approach would have been of greater value, that is to say, variations in the approach to indexing systems, patterns of bibliography, and the like. The references at the end of the work are principally to material in the English language.

It is easy, however, to criticize this work in its attempted coverage, because in order to produce a more satisfactorywork one would need to visit each country covered and examine services in depth or to produce a brief for industrial managers on the value of library services. One can perhaps hope that later volumes in this series will follow the pattern of the first volume in the series which covered special libraries in the Netherlands studies in depth of one country's special library services. One small quibble a more appropriate title might have been "Library" Services to Industry Throughout the World", becausi services provided by public and academic libraries are discussed in the volume. Patricia Layzell Ward

\section{Obiltuaries}

\section{Professor E. Lundsgaard}

Einar Lundggaard, who was born in 1899, died on December 18, 1968 .

He took a medical degree at the University of Copenhagen in 1923, and immediately began research on intermediary metabolism, which was to engage his attention 